ACTA THERIOLOGICA

Vol. 25, 5: 51-59, 1980

\title{
Factors Affecting Distribution and Removal Rates of Small Mammals in a Lowland Swamp Forest
}

\author{
Gary C. SMITH ${ }^{1}$, John B. GENTRY, Donald W. KAUFMAN ${ }^{2}$ \\ \& Michael H. SMITH
}

Smith G. C., Gentry J. B., Kaufman D. W. \& Smith M. H., 1980: Factors affecting distribution and removal rates of small mammals in a lowland swamp forest. Acta theriol., 25, 5: 51-59 [With 1 Table \& 2 Figs.].

Small mammals were snap-trapped on an octagon-shaped line transect $176 \mathrm{~m}$ on a side located in a lowland mesic-hardwood forest in the Southeastern United States. Two traps were set at each of 128 stations and 52 Ochrotomys nuttalli, 38 Peromyscus gossypinus, and 18 Blarina brevicauda were removed during a 28-day period. Differential removal rates for the three species were observed. The probability of capture seemed to vary as a function of microhabitat differences, species specific trap neophobia, and weather changes over the 28-day trapping period. Social interaction was not a factor in changing removal rates, since each species appeared to occur in different microhabitats. Cotton mice were associated with fallen trees (logs), golden mice with vines and short-tailed shrews with high amounts of leaf litter.

[Savannah River Ecology Laboratory, Drawer E, Aiken, SC 29801 USA].

\section{INTRODUCTION}

Early studies of small mammal species were designed to obtain a large catch in a given habitat or locality for museum specimens. More recent studies have attempted to develop standard procedures for estimating the density of different species (G r od z in sk i et al., 1966). Various factors have impeded the development of a standard small mammal trapping procedure including delayed capture of certain species ( $\mathrm{F}$ a ust et al., 1971; K a ufman et al., 1971), biases due to type of trap or trapping method used (S mith et al., 1971), social interactions and community organization ( $\mathrm{Calhoun}, 1964)$ and differences in microhabitat preferences of species ( $M^{\prime} \mathrm{C} l$ o s k e y, 1975). Instead of just considering social interactions as a complicating factor in making density estimates, trapping results can be useful in understanding inter- and

Current Address: ${ }^{1}$ Huxley College of Environmental Studies, Western Washington University, Bellingham, Wash. 98225. 2 National Science Foundation, Washington, D.C. 20550. 
intraspecific interactions ( $\mathrm{R}$ os e n z weig \& W in a k ur, 1969; J o u le \& $\mathrm{C}$ a m e r on, 1974; $\mathrm{S} \mathrm{m}$ it h et al., 1975).

The purpose of this study was to examine the trap response, habitat preference, and social interactions of small mammal species living in a lowland hardwood forest along the Savannah River in South Carolina. An attempt was made to correlate species distribution with microhabitat differences in vegetation and available cover. Information on habitat selection and trap response was used to test existing hypothesis on the cause of differential trap response of small mammal species. It is important to distinguish between the effects of interspecific interactions and of species-specific characteristics on trap response to more effectively design sampling programs for estimating small mammal densities.

\section{METHODS}

An octagon shaped trap line $176 \mathrm{~m}$ on a side was located in a lowland swamp forest on the Savannah River Plant $(S R P)$ in South Carolina ( $\mathrm{K}$ a u f m a $\mathrm{n}$ et al., 1971). Two snap traps, one Victor and one Museum Special, were placed at each of 128 stations around the octagon. Traps were baited with peanut butter, set and checked daily for 28 days. Trapping was conducted during the winter months of January and February when vegetation was relatively sparse. Species, location of capture, weight, sex, and reproductive condition of each mammal were recorded.

The study area was a lowland hardwood-swamp forest of flat terrain with sections covered by temporary or permanent standing water. Most of the hardwood trees were lowland oaks (Quercus sp.), sweet gum (Liquidambar styraciflua), and black gum (Nyssa sylvatica). Pine trees (Pinus sp.) occurred in the drier areas while cypress (Taxodium sp.) were found in areas of temporary and permanent standing water. Many shrubs and trees were covered with vines (Vitis sp.) and greenbrerier (Smilax sp.). Palmetto (Sabal palmetto) was the dominant understory vegetation. Fallen trees were present in parts of the trapping area as a result of logging operations in the early 1950's. Rating of the habitat at each station along the octagon line transect indicated three primary habitat types labelled as follows: (1) logs (numerous logs with few vines and some palmetto), (2) vines (numerous vines with some palmetto and few logs) and (3) palmetto (heavy palmetto with few vines and few logs).

\section{RESULTS}

One hundred and ten small mammals were captured during 28 days of trapping. Golden mice (Ochrotomys nuttalli), 52 individuals represented $47.3 \%$ of the total; cotton mice (Peromyscus gossypinus), 38 individuals and $34.5 \%$; short-tailed shrews (Blarina brevicauda) 18 individuals and $16.4 \%$; and wood rats (Neotoma floridana), 2 individuals and $1.8 \%$. The latter are not included in further analyses of the data. 
All $O$. nuttalli and $B$. brevicauda were adult animals with body weights within the range of adult weights for these species (G o l l e y, 1966). A small percentage of $P$. gossypinus were below recorded adult weights for this species and retained some remnants of juvenile pelage color. Animals captured at the beginning of the study showed no signs of reproductive activity (enlarged and descended testes, embryos, or lactation) with the exception of one $P$. gossypinus which was lactating during F'ebruary. O'F a rrell et al. (1977), summarizing data from eight years of trapping on the Savannah River Plant, found that reproductive peaks for the three mammal species in this study do not occur in January and February.

Chi-square analysis of the number of males to females of $P$. gossypinus $\left(\chi^{2}=2.25\right), O$. nuttalli $\left(\chi^{2}=0.19\right)$, and $B$. brevicauda $\left(\chi^{2}=0.00\right)$ showed no significant difference from a 50:50 ratio. Other studies involving removal trapping found differences in the sex ratios of one or more of these three species.

Considering the total numbers of animals of each species captured in 28 days as $100 \%, 50 \%$ of the P. gossypinus were removed by day 10 but not until day 20 for $O$. nuttalli and B. brevicauda (Fig. 1). Peromyscus gossypinus and $O$. nuttalli were both captured on the first day of trapping, while the first $B$. brevicauda was not captured until day 11 . The rate of capture of small mammals did not decline in a constant or predictable way over the 28-day trapping period. Secondary increases in capture rate began on day 16 for $O$. nuttalli and $B$. brevicauda; no change in the capture rate of $P$. gossypinus was observed at this time. Had the trapping been terminated prior to day 16 , as is the usual case, almost $75 \%$ of the total number of animals captured in 28 days, would not have shown up in the sample. In the case of $O$. nuttalli and $B$. brevicauda slightly more than $10 \%$ of the total number captured were removed prior to the 16 th day. With only six days remaining in the trapping period, approximately one third of the total number captured were still to be captured. Using assessment lines to measure the area of effect of the octagon, the density of all small mammals around the octagon was calculated as 7.09 /ha ( $\mathrm{Ka} \mathrm{ufman}$ et al., 1971).

Habitat designation for the trap stations were logs (44 stations), vines (44 stations), and palmetto (40 stations). There was a significant relationship between the distribution of captures and the three habitat types (Table 1). Captures of $P$. gossypinus were significantly greater in areas with logs than in areas without $\operatorname{logs}\left(\chi^{2}=37.6, P<.01\right)$. There were no captures of cotton mice at stations with vines $\left(\chi^{2}=19.9, P<.01\right)$. Significantly more $O$. nuttalli were taken from areas without logs when compared to areas with numerous $\operatorname{logs}\left(\chi^{2}=12.0, P<.01\right)$. There were 
significantly more $B$. brevicauda captured in areas without logs or palmettos than in other areas $\left(\chi^{2}=9.43, P<.01\right)$. The areas with palmettos tended to be relatively damp and not-suitable habitat for a semifossorial animal like B. brevicauda. Comparison of total zaptures of small mammals in the three habitat types indicated no significant difference in the total number of captures in any habitat from those expected based on numbers of trapping stations in each habitat type (Table 1).

\section{Table 1}

Results of Chi-square analyses of the number of captures of each species and all species combined observed in the three habitat types of the lowland hardwood forest. Expected values were calculated in relation to total number of trap stations.

\begin{tabular}{|c|c|c|c|c|c|}
\hline \multirow{2}{*}{ Species } & \multirow{2}{*}{$\begin{array}{l}\text { Habitat } \\
\text { Type }\end{array}$} & & \multicolumn{2}{|c|}{ Number Captured } & \multirow[b]{2}{*}{ Chi-Square } \\
\hline & & & Observed & Expected & \\
\hline $\begin{array}{l}\text { Peromyscus } \\
\text { gossypinus }\end{array}$ & $\begin{array}{l}\text { Logs }^{1} \\
\text { Vines }^{2} \\
\text { Palmetto }^{8}\end{array}$ & & $\begin{array}{r}31 \\
0 \\
7 \\
38\end{array}$ & $\begin{array}{l}13.1 \\
13.1 \\
11.9 \\
38.1\end{array}$ & $39.71 * *$ \\
\hline $\begin{array}{l}\text { Ochrotomys } \\
\text { nuttalli } \\
\text { Subtotal }\end{array}$ & $\begin{array}{l}\text { Logs } \\
\text { Vines } \\
\text { Palmetto }\end{array}$ & - & $\begin{array}{r}6 \\
26 \\
20 \\
52\end{array}$ & $\begin{array}{l}17.9 \\
17.9 \\
16.3 \\
52.1\end{array}$ & $12.45 * *$ \\
\hline $\begin{array}{l}\text { Blarina } \\
\text { brevicauda }\end{array}$ & $\begin{array}{l}\text { Logs } \\
\text { Vines } \\
\text { Palmetto }\end{array}$ & & $\begin{array}{r}0 \\
17 \\
1 \\
18\end{array}$ & $\begin{array}{r}6.2 \\
6.2 \\
5.6 \\
18.0\end{array}$ & $28.87 * *$ \\
\hline All species & $\begin{array}{l}\text { Logs } \\
\text { Vines } \\
\text { Palmetto }\end{array}$ & & $\begin{array}{r}37 \\
43 \\
28 \\
108\end{array}$ & $\begin{array}{r}37.1 \\
37.1 \\
33.8 \\
108.0\end{array}$ & $1.93^{\mathrm{ns}}$ \\
\hline
\end{tabular}

1 Deciduous forest with logs, few vines and palmetto. 2 Deciduous forest with numerous vines, and palmetto but not logs. ${ }^{3}$ Deciduous forest with heavy palmetto, few vines and no logs.

** Significant at the .01 level. ns Not significant at the .05 level.

There was a delayed response to the traps by both golden mice and short-tailed shrews (Fig. 1). The three species tended to be captured in different areas along the octagon (Fig. 2). Cotton mice and golden mice were captured together at only four stations, golden mice and short-tailed shrews were never trapped together at the same station. The Chi-square values for the coefficients of interspecific association between the three species were not significant at the .05 level (S o $u$ thw o od, 1971). The associations tested were cotton mice and golden mice $\left(\chi^{2}=2.51\right)$, golden mice and short-tail shrews $\left(\chi^{2}=.08\right)$, and cotton mice and short-tail shrews $\left(\chi^{2}=.59\right)$. The species were apparently distributed in different habitats and tended to be captured at 


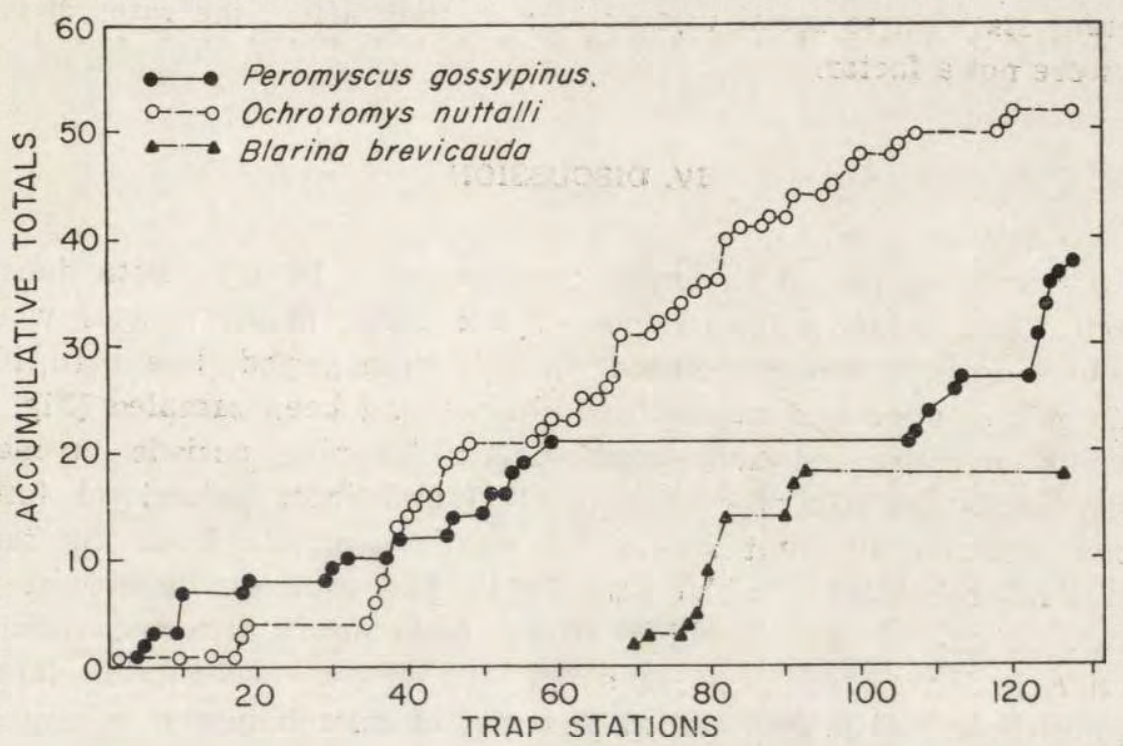

Fig. 1. Accumulative captures as a percent of the total number of Peromyscus gossypinus $(\mathrm{N}=38)$, Ochrotomys nuttalli $(\mathrm{N}=52)$, and Blarina brevicauda $(\mathrm{N}=18)$ caught during 28 days of trapping. Some of the daily data are not plotted to simplify the figure.

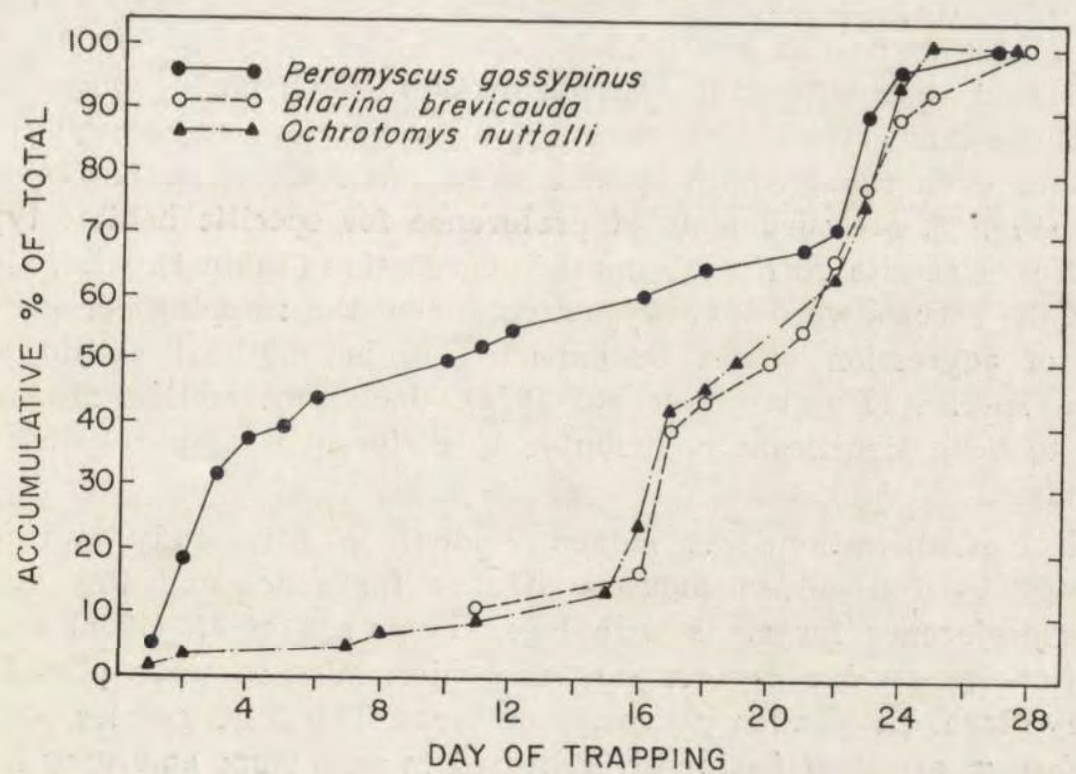

Fig. 2. Distribution of accumulative captures of Peromyscus gossypinus, Ochrotomys nuttalli and Blarina brevicauda at trap stations along the octagon transect. The distance between trap station was $11 \mathrm{~m}$. 
different stations, so social interactions as they affect the rates of capture were not a factor.

\section{DISCUSSION}

If the trapping period had been terminated at 14 days, both density estimates and relative frequencies of the three major species would have been grossly misrepresented. In this time period, less than $10 \%$ of the golden mice and short-tailed shrews had been sampled (Fig. 1). Previous investigators have used shorter trapping periods to make density estimates (B a r behenn, 1974) and infer behavioral interactions between different species of small mammals from the same general macrohabitat ( $\mathrm{C} 1 \mathrm{~h}$ o u n, 1964). The complex behavioral responses of many species which affect movement patterns, habitat selection and trap response of small mammals necessitate longer trapping times and more detailed analyses of microhabitats.

At least four hypotheses have been proposed for differential trap responses in small mammals: dominant species effects due to social interaction (C a l hou n, 1964), vertical stratification of habitats resulting in reduced exposure to traps (B a r b e h e $\mathrm{n} n$, 1973), "strange object reactions " or trap neophobia or neophilia (F a u s t et al., 1971) and differential activity due to weather changes (Gentry et al., 1971). Examination of distribution of animals around the octagon shows that golden mice and cotton mice were almost completely segregated from each other even though both species were relatively abundant in this habitat (Fig. 2). Measurements of preference for specific habitat types for each species also verify this spatial segregation (Table 1). Also, since none of the species were sexually active during the trapping period, the degree of aggression would be expected to be minimal within and between species (Turner et al., 1975). Social interaction does not appear to be a significant contributor to differential trap response in this study.

Vertical stratification was indeed evident in this study and was illustrated by the golden mouse's affinity for vines and the cotton mouse's preference for areas with logs. Gentry et al. (1968) found a significantly greater capture rate of golden mice in traps placed at about eye level on wooden platforms on trees. The third species, shorttailed shrews, are most frequently captured in snap traps emerging from the leaf litter or underground burrows ( $\mathrm{Barbeh} \mathrm{nn}, 1973$ ). The distribution of these three species in the lowland swamp forest could be superficially viewed as a classic case of niche diversification. Indeed, 
the arboreal species (golden mice) and the semifossorial species (shorttailed shrews) do have overlapping ranges. However, there is clearly a horizontal stratification between the two rodent species abundant in this area. Thus, placement of traps at more than one vertical position (perhaps three traps with one above ground, one on the ground surface, and one in a subsurface burrow at each station) may result in more trap encounters for species with vertically stratified niches and reduce the initial lag in captures.

Perhaps the greatest cause of delayed captures of animals was the response of the animals to the traps. F a u s t et al. (1971) found similar delayed trap response in the three species captured in the present study when using live traps. Insectivores seem to have a particularly strong 'neophobic response to traps. Smith et al. (1975) has reported that most insectivores fall into the category of having a slow removal rate. Since social interactions of the insectivore species may vary considerably from one habitat to another, the general trend of slow removal rates in insectivores (and also some rodent species) is probably the result of trap neophobia, but this behavior can obviously be modified by local conditions and state of the populations. Prebaiting for periods up to a week permits animals to become familiar with the traps and reduces some of the initial capture lags which occur with these species (G e n t r y et al., 1971).

In previous studies (G e n try et al., 1971), changes in weather have resulted in an increased capture rate for the three species represented in the present study. In the present study, rain on the sixteenth day and an ice storm on the twenty-second day were followed by significant surges in small mammal captures. Weather changes seem to alter the trap response of all three of these species.

The necessity for environmental impact statements in recent years has created a need for a quick, efficient, accurate method or methods for the assessment of small mammal species in many different habitats. Social interaction, trap neophobia and neophilia, weather, niche diversification, and other factors have been summarized by S mith et al. (1975) as variables affecting the capture rates of small mammals. Information from this summary and the present study illustrate the need to examine each of these variables carefully before beginning a small mammal census or attempting to estimate density.

Acknowledgments: This work was supported by contract EY-76-C-09-0819 between the United States Energy and Development Administration and the University of Georgia. Marie Jones helped with various parts of the study. 


\section{REFERENCES}

1. B a r behenn K. R., 1973: The use of stratified traps in estimating density: Peromyscus and Blarina. Acta theriol., 18: 395-402.

2. Barbehenn K. R., 1974: Estimating density and home range size with removal grids: the rodents and shrews of Guam. Acta theriol., 19: 191-234.

3. Calhoun J. B., 1964: The social use of space. [In: Mayer W. \& Van Gelder R., Eds. "Physiological Mammalogy«, Vol. 1.]. Academic Press: 1-187. New York.

4. Fa ust B. F., S mith M. H. \& Wra y W. G., 1971: Distances moved by small mammals as an apparent function of grid size. Acta theriol., 16: 111-177.

5. Gentry J. B., Golle y F. B. \& S mith M. H., 1968: An evaluation of the proposed International Biological Program census method for estimating small mammal populations. Acta theriol., 13: 313-327.

6. Gentry J. B., Golley F. B. \& S mith M. H., 1971: Yearly fluctuations in small mammal populations in a Southeastern United States hardwood forest. Acta theriol., 15: 179-190.

7. Gol1e y F. G., 1966: South Carolina Mammals. Contrib. Charleston Museum, 15: 1-181. Charleston, South Carolina.

8. Grodziński W., Pucek Z. \& Ryszkowski L., 1966: Estimation of rodent numbers by means of prebaiting and intensive removal. Acta theriol., 11: $297-314$.

9. Joule J. \& Cameron G. N., 1974: Field estimation of demographic parameters: influence of Sigmodon hispidus population structure. J. Mamm., 55: $309-318$.

10. Ka ufman D. W., Smith G. C., Jones R. M., Gentry J. B. \& Smith M. H., 1971: Use of assessment lines to estimate density of small mammals. Acta theriol., 16: 127-147.

11. M'Closkey R. T., 1975: Habitat dimensions of white-footed mice, Peromyscus leucopus. Amer. Midl. Nat., 93: 158-167.

12. O'Farrel1 M. J., Kaufman D. W., Gentry J. B. \& Smith M. H., 1977: Reproductive patterns of some small mammals in South Carolina. Fla. Scientist, 40: 76-84.

13. Rosenzweig M. L. \& Winakur J., 1969: Population ecology of desert rodent communities: habitats and environmental complexity. Ecology, 50: 558-572.

14. Smith G. C., Kaufman D. W., Jones R. M., Gentry J. B. \& Smith M. H., 1971: The relative effectiveness of two types of snap traps. Acta theriol., 16: $284-288$.

15. Smith M. H., Gardner R. H., Gentry J. B., Kaufman D. W. \& O'F a rre 11 M. J., 1975: Density estimations of small mammal populations. [In: Golley F. B., Petrusewicz K. \& Ryszkowski L., Eds.]. Univ. Press: 25-53. London.

16. Southwood T. R. E., 1971: Ecological methods. Chapman and Hall Ltd.: 1-328. London, England.

17. Turner B. N., Perrin M. R. \& I vers on S. L., 1975: Winter coexistence of voles in spruce forest: relevance of seasonal changes in aggression. Can. J. Zool., 53: 1004-1011.

Accepted, October 31, 1979. 
Gary C. SMITH, John B. GENTRY, Donald w. KAUFMAN i Michael H. SMITH

CZYNNIKI WPEYWAJACE NA ROZPRZESTRZENIENIE I POZIOM WYEOWU MAEYCH SSAKOW W LESIE BAGIENNYM

\section{Streszczenie}

Małe ssaki odławiano zatrzaskami na ośmiobocznym, liniowym transekcie o długości boku $176 \mathrm{~m}$, zlokalizowanym $\mathrm{w}$ bagiennym lesie, w południowo-wschodniej części Stanów Zjednoczonych. W każdym ze 128 punktów ustawiano po dwie pułapki i w ciągu 28 dni złowiono 52 Ochrotomys nuttalli, 38 Peromyscus gossypinus i 18 Blarina brevicauda (Ryc. 1). Stwierdzono zróżnicowanie tempa wyłowu omawianych gatunków (Ryc. 2). Prawdopodobieństwo złowienia wydawało się byé funkcją zróżnicowania mikrośrodowiska, specyficznego oddziaływania pułapki na dany gatunek i zmian pogodowych w ciągu okresu wyłowu. Socjalna interakcja nie była czynnikiem zmieniającym poziom wyłowu, ponieważ każdy gatunek występuje w różnych mikrośrodowiskach. Peromyscus gossypinus spotyka się przy przewróconych pniach drzew, Ochrotomys nuttalli w miejscach porośniętych przez Vitis sp. a Blarina brevicauda w ściole w pobliżu drzew liściastych (Tab. 1). 